https://doi.org/10.18485/iipe_conv_conf.2021.ch7

\title{
ICT AND THE CONVERGENCE OF THE MIDDLE EAST TO THE DEVELOPED ECONOMIES
}

\begin{abstract}
Nataša Stanojević1
Abstract: The focus of this research is the problem of the constant lag in the economic development of the Middle East region. Due to numerous specifics and limitations, these countries are not subject to conventional development models. One of the newer development opportunities is offered by Information and Communication Technologies (ICTs), which bypass many earlier obstacles to the development of this region. The review of previous research, as a starting point for this paper, includes both theoretical assumptions about the mechanisms of positive effects of ICTs on economic development and empirical research results that do not indicate such clear positive effects, especially in less developed economies. The general hypothesis is that ICTs have both converging and diverging effects on the development of the Middle Eastern economies. ICTs implementation in these undiversified economies has very limited scope, while investing in ICTs has a strong positive effect on economic growth. The methods used are the classification of ICTs determinants in the region as well as the Pearson coefficient of correlation between investment in ICTs and economic growth. The summary results show that ICTs have significant development potential for the region only if they are implemented in specially selected segments of the economy for each individual country.

Keywords: Information and Communication Technologies (ICTs), the Middle East, Network readiness index (NRI), economic development, spending, investments.
\end{abstract}

\footnotetext{
${ }^{1}$ Ph.D. Institute of International Politics and Economics, Belgrade. natasa.stanojevic@diplomacy.bg.ac.rs

The paper presents the findings of a study developed as part of the research project entitled "Serbia and Challenges in International Relations in 2021", financed by the Ministry of Education, Science, and Technological Development of the Republic of Serbia, and conducted by the Institute of International Politics and Economics, Belgrade.
} 


\section{INTRODUCTION}

The key differences between developed and developing economies that are commonly cited in the literature are: high income, usually measured by per capita income; dominance of the service sector in GDP; technological advancements; high level of infrastructure development; high human development rank in terms of education quality and health; and others. The criterion included in all classifications is high income, as the main difference between the developed and underdeveloped worlds. However, such a clear distinction cannot be made between the economies of the countries of the Middle East and developed economies. Some of the countries in the region, such as Qatar, the UAE, Kuwait, and Saudi Arabia, have higher per capita incomes than the US and most of the most developed economies in Western Europe. Wealthy Arab economies also have the highest level of infrastructure. Nevertheless, this region does not belong to the group of developed economies, just as it cannot be called underdeveloped. A crucial step that separates the Middle East from the developed world is advanced technology, education, and skills.

In this article, Information and Communication Technologies (ICTs) are seen as a characteristic of competitiveness but at the same time as a means of stimulating economic growth and development in general, including many aspects of human development.

ICTs have the potential to accelerate economic development by stimulating productivity and employment growth in services, industry, and agriculture. Of particular importance for the Middle East region, including North Africa (hereinafter the Middle East), is the fact that ICTs do not depend on natural conditions and resources, which are very unfavourable in this region, not even on the achieved stage of industrialization, which is lagging behind in most of these countries.

Having in mind the monolithic structure of the Middle Eastern economies, two special hypotheses can be set. The first is that investing in ICTs has a strong positive effect on their economic growth by raising the level of invested capital and engaging additional labour in a new sector. On the other hand, it is precisely this monolithic structure of the economy and the lack of productive activities that significantly narrow the possibility of realising the full potential of ICTs, which is usually related to increasing productivity and 
efficiency. Therefore, the general hypothesis is that ICTS have both converging and diverging effects on the development of the Middle Eastern economies.

The main problem with generalising the effects of ICT investment is that developing countries may lack the capacity to absorb these technologies. This can happen if, for example, they do not have the appropriate level of human capital or simply do not have enough capital to complete the started phases but remain with the commenced projects, unfinished ICT infrastructure, and the like. Thus, the effects of investment can be significantly smaller than in developed countries. Developing countries, on the other hand, in the modern period feel fewer positive effects of new investment in ICTs because the most advanced technologies have already been implemented in all segments of the economy and society and have strongly contributed to the development of these economies.

Despite these barriers, directing additional resources to encourage the implementation of ICTs generally contributes to the growth and development of all economies. However, for the Middle Eastern countries, this may be more important, because this is one of the few development options that fits into their non-productive position in the world market and bypasses existing internal natural and social barriers to development. ICTs could enable these countries to "skip" the industrialization phase and the usual methods of increasing productivity, as shown by the modern rise of the Indian economy.

This research analyses the state and potential of ICTs development in the Middle East. All segments of technological readiness, according to the classification of the World Economic Forum (WEF), are compared with developed economies in order to determine how much the countries of the Middle East converge with those that belong to the "developed world". The specific goal is to determine whether investing in ICTs, as a sector, has a positive and significant relationship with economic growth in these countries.

The first chapter refers to the literature review of the impact of ICTs on the economy and consists of two parts. The first sub-chapter explores the theoretical assumptions of this impact, and the second one presents empirical research on this impact on specific economies.

The second chapter describes in detail the state of ICTs in the Middle East, following the criteria of the 2016 Networked Readiness Index (NRI) of the WEF. According to these criteria, the following were investigated: the ICTS environment in these countries, the readiness for ICTs implementation, the 
scope of ICTs use by individuals, companies, and governments, as well as the impact of ICTs on the economies and societies of these countries. All these criteria are analysed in separate sub-chapters. Each of them is further divided into several indicators, so that this chapter presents the state of ICTs not by simple description, but in depth and quantitatively.

The third chapter is a quantitative study of the effects of investing in the ICTs sector in all Middle Eastern countries. The Pearson coefficient was applied, which determines the correlation between ICTs investments and their economic growth, measured by GDP growth and GDP per capita.

\section{LITERATURE REVIEW ON THE IMPACT OF ICTS ON THE ECONOMY}

\section{Theoretical assumptions about the impact of ICTs on development}

Information and communication technologies have a direct or indirect impact on the entire economy. In developing countries, "information and communication technologies can reduce poverty" ${ }^{2}$, increase productivity, and stimulate economic growth". ${ }^{3}$ The most common ways of influencing are: changes in product type, production (productivity), trade, banking, and governance (e-government), increasing efficiency, increasing the quality of human resources, etc.

Production in the field of ICTs is characterised by rapid technological development and strong demand, which makes a great contribution to the development of the economy, business, and exports. The developed ICTs sector enables companies to achieve advantages through the development of technologies for certain purposes. These technologies have found wide application in services, industry, and even agriculture, and they greatly encourage the growth of productivity in these sectors.

One of the most important aspects of the impact of ICTs sector production and services on the economy is the impact on employment. It is not only

\footnotetext{
${ }^{2}$ These are not direct effects, but the development of ICTs enhances people's economic opportunities and access to financial resources, as well as information on government policies, social services, health care, and education.

${ }^{3}$ World Bank, ICT for Greater Development Impact. Washington, D.C.: World Bank Group, 2012.
} 
about increasing employment, but also about big changes in the quality of the workforce (education and skills), as well as its distribution by sectors and geographical locations. In telecommunications companies, employment is not increasing faster than the increase in assets and income. Digitalization in these groups has not so far affected the increase in the number of jobs. In contrast, after 2015, the number of employees in multinational corporations with a technical profile increased by about $5 \%$ per year. In addition to contributing to overall employment, it is of some importance to create new employment opportunities within the ICTs sector.

To some extent, ICTs contribute to economic growth and productivity directly through the opening of new companies in this sector. By founding these companies, GDP automatically increases for the year in which they are founded. ICT companies, such as telecommunications services, have the largest share among start-ups. The success of their businesses in the coming years (and these companies are growing faster than in other sectors of the economy) will make an additional contribution to economic growth. At the same time, successful business does not depend so much on the ability of management, but on the growth of the number of consumers and new needs, thus new services, in the field of communications at the global level. These new services are, for example, electronic commerce, electronic financing, electronic management, and the like. These new services contribute to increasing economic activity. More intensive application of ICTS contributes to the reduction of transaction costs and accelerates innovation processes. This further encourages multifactorial productivity and thus the overall efficiency of the economy. ICTs enable cost reduction and faster and better communication between business entities; contribute to process and inventory optimization in factories; play an important role in retail ICTs through automated payments, scheduling optimization, inventory control, and more. ${ }^{4}$

The relationship between technology and employment is a bit controversial. Although high technologies create new markets, new jobs, and business ventures, they simultaneously lead to disruptions in existing manufacturing sectors and the labour market. The rapid development of ${ }^{4}$ UNCTAD, World Investment Report 2018 - Investment and New Industrial Policies, Geneva:
United Nations, 2018: 9. 
information and communication technologies has led to a change in the way individuals work and the nature of jobs available in the labour market. Changes and the development of information and communication technologies are related to the transformation of job characteristics at the level of individual occupations as well as at the level of coordination and organization. These changes are related to the change in the requirements of the labour market in terms of qualifications and levels of expertise. In the Middle East, a potential problem would be that high technologies require far less labour in quantitative terms, but have increased demands on the quality of human resources in terms of education and skills. Teleworking is one of the most significant advantages of ICT. Some of the most important social benefits of teleworking are the expansion of the workforce by providing opportunities for wider sections of the population to engage in economic flows. This applies to people with disabilities, to women, enabling them to reconcile work with family obligations, and to the population in isolated areas, among others.

In addition to the economy, the application of high technologies has a strong, visible impact on the overall development of society. ICTs can facilitate access to basic services such as health (e-health services, disease monitoring), traffic monitoring and control, pollution monitoring, logistics in transport, and education (online courses). Information and communication technologies can help governments better understand and respond more quickly and adequately to social trends and events, such as changes in migration patterns and the needs of migrants. ICTs can facilitate the delivery of humanitarian aid. Governments in developing countries can facilitate anti-corruption efforts, increase traditionally very low efficiency (e-government), and information management can contribute to a better response to natural disasters, environmental disasters, and displacement. ${ }^{5}$

\section{Empirical research on the impact of ICTs on development}

Since the end of the 20th century, information and communication technologies have been considered a key driver of productivity growth.

\footnotetext{
${ }^{5}$ UNCTAD, World Investment Report 2017-The digital economy - the application of internetbased digital technologies to the production and trade of goods and services, Geneva: United Nations, 2017.
} 
However, in the mass of articles, strategies, books, and brochures, there is not much concrete quantitative research on the impact of ICTs on the economy. Most of the significant research is conducted by the OECD and refers to OECD countries, i.e., developed countries. Most of these studies have proven a positive and economically significant link between the state and dynamics of ICTs and economic growth.

Although the effects of the application of ICTs on development are experientially evident, very rare are scientific studies that measure the effects of the use of ICTs on economic growth. Even rarer are studies that analyse these effects in less developed and developing countries. Most notable is Wu, which investigates the impact of the use rates of computers in private use, mobile phones, and Internet users in 107 developed, underdeveloped, and developing countries on economic growth. ${ }^{6}$ No distinction was made between these groups of countries, but they entered the sample together, and the research showed generally positive effects of ICTs application on growth.

Research by Niebel and Yousefi analysed the impact of ICTs investment on economic growth and their results indicate a strong positive relationship. ${ }^{7}$ Nibel's research is one of the few that analyses developed, underdeveloped, and developing countries separately. The results are approximately the same, with little advantage in developed countries. Stiroh finds a negative correlation. But in a repeated study, with the same methodology and with extended results, he obtained a positive link between ICTs investment and economic growth. ${ }^{8}$ More significant studies of this relationship are by Strauss and Samkharadze, O'Mahony and Vecchi, Papaioannou and Dimelis with positive results, and Pilat with negative results or no effects of ICTs investments. ${ }^{9}$

\footnotetext{
${ }^{6}$ Khuong Vu, "ICT as a Source of Economic Growth in the Information Age: Empirical Evidence from the 1996-2005 Period". Telecommunications Policy, 35(4), 2011.

${ }^{7}$ Thomas Niebel, "ICT and Economic Growth - Comparing Developing, Emerging and Developed Countries," World Development, 104(C), 2018; Ayoub Yousefi, "The impact of information and communication technology on economic growth: evidence from developed and developing countries", Economics of Innovation and New Technology, 20(6), 2011.

${ }^{8}$ Kevin Stiroh, "Are ICT Spillovers Driving the New Economy?" Review of Income and Wealth, 48(1), 2002

${ }^{9}$ Hubert Strauss and Besik Samkharadze, "ICT Capital and Productivity Growth." EIB Papers, 16(2), 2011; Mary O'Mahony and Michela Vecchi, "Quantifying the Impact of ICT Capital
} 
An extensive OECD survey from 2003, entitled "OECD, ICT and Economic Growth: Evidence from OECD Countries, Industries and Firms", showed that investing in ICTs has contributed to growth and productivity in all OECD countries. However, the impact is not evenly balanced. In the United States, this impact is far greater than in any other OECD country. In some countries, namely the US and Australia, the research showed that the sectors that invested a lot in ICTs had faster productivity growth. This is especially true for the wholesale and retail trade.

There is little research on the impact of ICTs investment on the economic growth and development of underdeveloped and developing countries, and the existing empirical evidence is relatively weak and contradictory, mainly as a result of the lack of reliable data.

A few in-depth studies relate to determining the correlation between several parameters of the state and dynamics of ICT in the analysed countries and economic growth. The mentioned Niebel research is based on a sample of 59 countries in a period of 5 years (1995-2010) and confirms the hypothesis of a positive relationship between capital invested in ICTs and GDP growth. ${ }^{10}$ In this study, underdeveloped countries, emerging economies, and developed countries were analysed separately. What is interesting in this study is that there is no statistically significant difference between them in terms of the degree of impact of ICTS on the growth of their economies.

Karlsson and Liljevern investigated the impact of ICTs investments on production growth, with countries divided into four groups according to the criterion of total revenues..$^{11}$ The panel analysis is based on a sample of 101 countries from 1995 to 2015. The extended Cobb-Douglas production function was applied. The results showed that in the lowest income countries

on Output Growth: A Heterogeneous Dynamic Panel Approach", Economica 72(288), 2005; Papaioannou, Sotiris and Dimelis Sophia. "Information Technology as a Factor of Economic Development: Evidence from Developed and Developing Countries," Economics of Innovation and New Technology 16(3), 2007; Dirk Pilat, "The ICT Productivity Paradox: Insights from Micro Data", OECD Economic Studies, 1, 2004.

${ }^{10}$ Niebel, "ICT and Economic Growth - Comparing Developing, Emerging and Developed Countries."

${ }^{11}$ Emil Karlsson and Jennie Liljevern. ICT Investment and the Effect on Economic Growth - a Comparative Study across Four Income Group. Jönköping: Jönköping University, 2017. 
(only seven countries), the positive effect of investing in ICTs on economic growth is completely absent. Similar results are given by the analysis of Hanclova et al., which also points to the weak effects of ICTs on economic growth in Eastern European countries. ${ }^{12}$

This article strongly relies on Stanojević's research, in which the effect of investing in ICTs on the economic growth of the Middle Eastern countries is analysed and a strong positive correlation is obtained. ${ }^{13}$

\section{COMPETITIVENESS AND TECHNOLOGICAL READINESS IN THE MIDDLE EAST}

Globalization and the Fourth Industrial Revolution have created many new development opportunities, but also disruptions within and between economies and societies. ${ }^{14}$ In that context, in 2018, the WEF created a new Competitiveness Index 4.0. In addition to the previous competitiveness factors (called competitiveness pillars), index 4.0 includes ICTs, innovation capacity, information infrastructure, and other factors (Table 1).

Table 1. Factors (pillars) of competitiveness in the Middle East

\begin{tabular}{|l|c|c|}
\hline Pillars of competitiveness & Index (1-100) & $\begin{array}{c}\text { Growth compared to the } \\
\text { previous period }\end{array}$ \\
\hline Institutions & 55.5 & 1.2 \\
\hline Infrastructure & 70.5 & 1.4 \\
\hline ICT adoption & 57.6 & 4.8 \\
\hline Macroeconomic stability & 75.3 & -4.3 \\
\hline Health & 80.8 & 1.0 \\
\hline
\end{tabular}

12 Jana Hanclova et al. "Does ICT capital affect economic growth in the EU-15 and EU-12 countries"? Journal of Business Economics and Management, 16(2).

${ }^{13}$ Nataša Stanojević, Karakteristike privreda Bliskog istoka i Severne Afrike i perspektive ekonomske saradnje sa Srbijom, (Beograd, Institut za međunarodnu politiku i privredu, 2021).

${ }^{14}$ Klaus, Schwab, (ed.), The Global Competitiveness Report 2019, Geneva: World Economic Forum, 2019. 


\begin{tabular}{|c|c|c|}
\hline Pillars of competitiveness & Index (1-100) & $\begin{array}{c}\text { Growth compared to the } \\
\text { previous period }\end{array}$ \\
\hline Skills & 62.9 & 1.1 \\
\hline Commodity market & 56.7 & 2.7 \\
\hline Job market & 54.8 & 3.4 \\
\hline Financial system & 63.7 & 2.2 \\
\hline Market size & 59.9 & 1.0 \\
\hline Business dynamics & 58.2 & 2.1 \\
\hline Innovative ability & 41.3 & 4.3 \\
\hline
\end{tabular}

Source: Schwab, 2019.15

The Middle East, compared to other regions, has a relatively high infrastructure index and ICTs adoption as factors of competitiveness. The nation's health index is itself the largest (80), but compared to other regions, it is higher only than South Asia and sub-Saharan Africa. ${ }^{16}$ The weakest index has the factor of innovation ability, although this factor is relatively low-rated in other regions as well.

Among the mentioned factors of competitiveness, ICTs adoption stands out as a potential driver of future growth in the competitiveness of the Middle Eastern economies. The reason is the relatively good position compared to other regions, but above all, the higher growth of the index compared to the previous period. As the data in Table 1 shows, other factors are stagnant or declining. An important feature of information technologies is that they support not only business and efficiency, but also the economic sector itself, which, like other economic activities, includes domestic and foreign investments, significant revenues, and jobs. Unlike manufacturing, there are no requirements in terms of geographical conditions and resources, which the region does not have. These countries cannot develop industry, but they

\footnotetext{
${ }^{15}$ Ibid.

${ }^{16}$ Ibid.
} 
are part of global value chains as transportation hubs, with the potential to become financial hubs like the UAE and Bahrain. Both positions require a wide implementation of the latest information technologies. ICTs can overcome many weaknesses in Arab economies, contribute to diversification by creating a number of new economic opportunities, raise the level of education, which is constantly low in this region, and contribute to inclusion in trends and trends in the world economy and global value chains.

In order to gain a more detailed insight into the state and perspectives of ICTs as a driver of competitiveness growth, it is necessary to determine the technological level of these countries. Quantitatively, the technological level is most often expressed by the Networked Readiness Index (NRI), which is also called technological readiness. This is a tool for assessing the readiness of countries to take advantage of new ICTs and digital transformation. The original index was developed in 2001 by the WEF. The goal was to better understand the impact of ICTs on the competitiveness of economies, and for this reason, this composite indicator had the following three components: 1. the ICTs environment offered by a particular country; 2 . society's willingness to use ICTs (individuals, companies, and governments); and 3. the scope of ICTs use.

The NRI is then systematically developed so that the categories it includes are partially different in each new model, which is created every four years. Although a new, slightly modified index was constructed in 2020, this research includes the classification of countries and the NRI categories from the previous report for 2016 because it referred more directly to the ICTs sector. The new index refers to a broader topic, the digital transformations of the entire society, and includes precisely the categories in which the countries of the Middle East lag behind: the inclusion of women, rural areas, and the like.

In the 2016 report, the NRI included 4 main categories, 10 subcategories (pillars), and 53 specific indicators that are integral parts of the subcategories. Indicators are rated 1-7. Each category will be considered in the context of the Arab countries and their global position in the areas covered by the pillars of competitiveness.

- ICTs environment; 1. Political and regulatory environment (9 indicators) 2. Business and innovation environment (9 indicators).

- ICTs readiness; 3. Infrastructure (4 indicators) 4. Availability (3 indicators) 5. Skills (4 indicators). 
- Use of ICTs; 6 . Individual usage (7 indicators) 7. Business usage (6 indicators) 8. Government usage (3 indicators).

- Impact of ICTs; 9. Economic impact (4 indicators) 10. Social impact (4 indicators).

139 countries were included in the analysis. Figure 1 shows the trend of the NRI, i.e., the trend of technological readiness in seven regions of the world. Trends for all four main categories of the information and communication technology sector in the period 2012-2016 are presented.

When comparing these trends, it is noted that the Arab countries (the Middle East group, North Africa, and Pakistan) do not lag behind other regions to which developing countries belong. Compared to Latin America and especially sub-Saharan Africa, Arab countries are better rated in all four categories (Figure 1).

Figure 1: Index of technology readiness

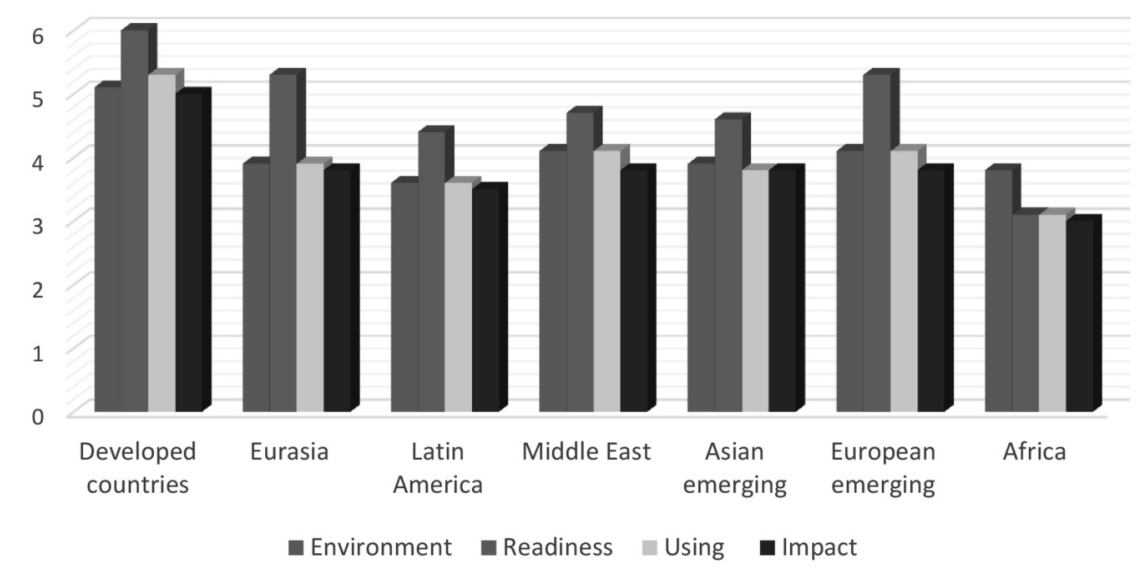

Source: author according Baller, Dutta and Lanvin, 2016. pp. 22-23. ${ }^{17}$

The countries of the Middle East lag far behind the developed countries in terms of all categories of NRIs. On the other hand, they are relatively

\footnotetext{
${ }^{17}$ Silja Baller, Soumitra Dutta, and Bruno Lanvin (eds), Technology Report 2016 - Innovating in the Digital Economy, Geneva, Geneva, World Economic Forum, 2016. pp. 22-23.
} 
uniform in all four categories with emerging Asian countries, which include China, Malaysia, Thailand, and other successful Asian economies. Compared to European emerging countries and Eurasian countries, the lag is significant only in terms of readiness to implement ICTs. In terms of the extent of ICTs use, only the most developed countries stand out, while all others are relatively uniform (Figure 1 ).

According to the total NRI, among the countries of the region, the richest countries are in the lead, namely the United Arab Emirates, Qatar, and Saudi Arabia. This order in the region is constant, but their position in the world is changing somewhat. In 2016, the UAE and Qatar took the 26th, 27th, and 33rd places in the world, and in 2020 they dropped to 30th, 38th, and 41st places.

Most Middle Eastern countries occupy 50 to 90 places in the world, which can be considered an average technological level of about 4 index points. Oman is in the 52nd place, Jordan in the 60th, Kuwait in the 61st, Morocco in the 78th, Tunisia in the 81st, and Lebanon in the 88th. Other Arab countries lag far behind in terms of technological level. Pakistan is 110, Algeria is 117, while Libya, Yemen, and Syria are not included in the report due to a lack of data, which in itself gives a picture of the technological level of these conflictaffected areas. Kuwait and Lebanon made the biggest progress compared to the previous period. Algeria has far greater financial opportunities for improving the technological level than all the countries in the second group, which speaks in favour of the fact that the technological level does not depend exclusively on investments. Many indicators do not actually require much investment. ${ }^{18}$

The cumulative index, however, in some cases, does not reveal the true picture of the ICTs sector in all countries. In the example of the UAE, an extremely large difference can be noticed in terms of certain pillars. The high position of the UAE is largely due to the government, which is second in the world in 2016 according to the criteria of government use of ICTs. Individual use of ICTs is in a high 19th place, especially in terms of the number of households with Internet access and mobile subscriptions. The adoption of ICTs in the business environment and the economic impact of ICTs have improved compared to the previous report. However, in terms of the most advanced economic activities, there is still a significant gap. Activities related

\footnotetext{
${ }^{18}$ Stanojević, Karakteristike privreda Bliskog istoka.
} 
to patents in general and patents in the field of ICTs are very low and reduce the overall NR index.

Due to such large differences between different aspects of ICTs within countries, it is necessary to analyze the state of the sector from the angle of four main categories of ICTs: environment, readiness for implementation, use, and impact.

\section{Information and communication environment in the Middle East}

The first category, the ICTs environment, relies on two pillars: the Political and Regulatory Environment and the Business and Innovation Environment. The political and regulatory environment includes indicators such as the efficiency of the legislature and the judiciary, ICTs-related laws, the independence of judges, the protection of intellectual property, software piracy, the number of days to execute contracts, and so on. The business environment includes the availability of the latest technologies, tax rates, the number of days required to start a business, the number of procedures for starting a business, some indicators related to the education system (not specifically for workforce qualifications) and the like. ${ }^{19}$

The assessment and ranking of countries with respect to these two aspects of the first category are shown in Table 2.

Table 2. ICTs environment in the Middle East countries

\begin{tabular}{|l|c|c|c|c|}
\hline & \multicolumn{2}{|c|}{$\begin{array}{c}\text { Political and Regulatory } \\
\text { Environment }\end{array}$} & \multicolumn{2}{c|}{$\begin{array}{c}\text { Business and Innovation } \\
\text { Environment }\end{array}$} \\
\hline Country & Rank & Value & Rank & Value \\
\hline Qatar & 18 & 5.3 & 15 & 5.3 \\
\hline UAE & 25 & 5.1 & 13 & 5.4 \\
\hline S. Arabia & 29 & 4.6 & 25 & 5.1 \\
\hline Bahrain & 36 & 4.3 & 29 & 5.0 \\
\hline
\end{tabular}

${ }^{19}$ Slobodan Kotlica and Nataša Stanoejvić. Tehnologija, inovacije i konkurentnost u globalizovanoj privredi. Beograd: Dositej, 2017. 


\begin{tabular}{|l|c|c|c|c|}
\hline \multirow{2}{*}{} & \multicolumn{2}{|c|}{$\begin{array}{r}\text { Political and Regulatory } \\
\text { Environment }\end{array}$} & \multicolumn{2}{c|}{$\begin{array}{c}\text { Business and Innovation } \\
\text { Environment }\end{array}$} \\
\hline Jordan & 39 & 4.2 & 38 & 4.8 \\
\hline Oman & 53 & 4.0 & 58 & 4.4 \\
\hline Kuwait & 63 & 3.8 & 72 & 4.2 \\
\hline Morocco & 70 & 3.8 & 87 & 4.1 \\
\hline Lebanon & 126 & 3.0 & 49 & 4.6 \\
\hline Tunisia & 90 & 3.5 & 112 & 3.7 \\
\hline Egypt & 102 & 3.3 & 113 & 3.7 \\
\hline Algeria & 123 & 3.0 & 133 & 3.2 \\
\hline
\end{tabular}

Source: author according to Baller, Dutta and Lanvin, 2016. ${ }^{20}$

Among the countries of the region, only Qatar and the UAE rank high, the 15th and 19th in the world, while several of the lowest ranked countries are below the 100th position (Egypt is 113, Pakistan 115, and Tunisia 109). In general, all Middle Eastern countries have a much better business than political-regulatory environment for the development of the ICTs sector.

\section{Readiness for implementation of ICTs in the Middle East}

The second category is the readiness to implement ICTs. It consists of three pillars: ICTs infrastructure, ICTs availability, and ICTs skills. Infrastructure in this context includes: electricity production per capita, mobile network coverage, and internet servers (number and security). Infrastructure is the most developed aspect of the second category in the countries of the Middle East. As many as five countries have an infrastructure rating higher than 5, which is close to the rank of the most developed countries (Table 3). It is interesting that Egypt has by far the weakest ICTs infrastructure, where tourism is one of the most important sources of income, and it is precisely the weak infrastructure that is the factor that most refers to visitors.

\footnotetext{
${ }^{20}$ Baller, Dutta, and Lanvin (eds), Technology Report 2016.
} 
The availability of ICTs implies the prices of mobile telephony services, the prices of the Internet, and the competitiveness of the Internet and telephony sectors. In terms of affordability, Egypt is highly ranked, with as many as 5.8 points. Above it, it is only Bahrain, with similar prices, and Morocco, with prices for the internet and mobile telephony that are among the lowest in the world. That is why this country has 6.3 out of a possible 7 points (Table 3 ). This is the result of a very low standard of living and prices in general, and not especially the development of the ICT sector. In contrast to these countries, Qatar, the UAE, and Saudi Arabia, which rank highest in the region in terms of overall index, rank very low in terms of availability, and rank between 101st and 120th. These rich countries have a very high standard of living, so the prices of the Internet and mobile telephony are in line with the general price level. Unlike the most developed countries, they have not provided the widest access to ICTs.

Table 3. Readiness for implementation of ICTs in THE Middle east countries

\begin{tabular}{|l|c|c|c|c|c|c|}
\hline & \multicolumn{2}{|c|}{ Infrastructure } & \multicolumn{2}{c|}{ Availability } & \multicolumn{2}{c|}{ Skills } \\
\hline Country & Rank & Value & Rank & Value & Rank & Value \\
\hline Bahrain & 31 & 5.8 & 40 & 5.9 & 31 & 5.7 \\
\hline Kuwait & 30 & 5.8 & 89 & 4.8 & 77 & 4.9 \\
\hline Qatar & 29 & 5.8 & 120 & 3.1 & 5 & 6.4 \\
\hline UAE & 28 & 5.9 & 116 & 3.4 & 22 & 5.8 \\
\hline S. Arabia & 36 & 5.2 & 101 & 4.3 & 49 & 5.4 \\
\hline Tunisia & 82 & 3.7 & 24 & 6.3 & 85 & 4.7 \\
\hline Oman & 46 & 4.9 & 96 & 4.6 & 76 & 5.0 \\
\hline Lebanon & 77 & 4.0 & 109 & 4.0 & 55 & 5.3 \\
\hline Jordan & 92 & 3.2 & 94 & 4.6 & 59 & 5.3 \\
\hline Morocco & 102 & 3.0 & 20 & 6.3 & 110 & 3.7 \\
\hline Algeria & 80 & 3.9 & 99 & 4.4 & 89 & 4.6 \\
\hline Egypt & 94 & 3.1 & 47 & 5.8 & 111 & 3.7 \\
\hline
\end{tabular}

Source: author according to Baller, Dutta and Lanvin, 2016. ${ }^{21}$

${ }^{21}$ Baller, Dutta, and Lanvin (eds), Technology Report 2016. 
The fifth pillar, i.e., the third in the category of readiness for the implementation of ICTs, is skills. This includes the quality of the education system, especially the quality of education in mathematics and science, the enrollment rate in secondary education, and the adult literacy rate. In this aspect, some countries in the region, such as Qatar, the United Arab Emirates, and Bahrain, achieve very good results, with an average score of 5.7 to as much as 6.4 in Qatar, which positions this country as the fifth in the world.

\section{Usage subindex}

The third category of technological readiness is the use of ICTs. It refers to the usage of information and communication technologies by individuals, economic entities, and the government. The performance of the Middle Eastern countries in these three pillars is shown in Table 4.

The highest rank in this category is held by the United Arab Emirates, Qatar, and Bahrain, where the use of ICTs by governments and individuals in these countries is far higher than the degree of use of ICTs by economic entities. In terms of individual use, it is not just the number of mobile phones, but in addition to mobile phone subscriptions, a number of indicators are included, such as the percentage of the population using the Internet, the percentage of households with computers, the number of households with Internet access, the use of virtual social networks and more. The UAE, Qatar, Bahrain, and Saudi Arabia have more than 6 points each, while the countries of North Africa have the least individual usage of ICTs, with Algeria at the bottom of the world list with 2.8 points (Table 4).

Business usage of ICTs is a separate pillar of the NRI. It includes indicators of technology absorption, the capacity of companies to innovate, the rate of patent applications, the use of information and communication technologies for business transactions, the use of the Internet between companies and consumers, and the level of training of staff to use ICTs. Business usage of ICTs in any country in the region did not reach five points, and the ranking is below one hundredth place in all countries of North Africa. 
Table 4. Level of ICTs usage in THE Middle east countries

\begin{tabular}{|l|c|c|c|c|c|c|}
\hline & \multicolumn{2}{|c|}{ Individual usage } & \multicolumn{2}{c|}{ Business usage } & \multicolumn{2}{c|}{ Government usage } \\
\hline Country & Rank & Value & Rank & Value & Rank & Value \\
\hline UAE & 19 & 6.2 & 27 & 4.6 & 2 & 6.2 \\
\hline Qatar & 23 & 6.0 & 25 & 4.8 & 5 & 5.5 \\
\hline Bahrain & 14 & 6.3 & 37 & 4.0 & 3 & 5.7 \\
\hline S. Arabia & 21 & 6.0 & 42 & 3.9 & 11 & 5.4 \\
\hline Oman & 39 & 5.3 & 94 & 3.4 & 34 & 4.7 \\
\hline Kuwait & 32 & 5.6 & 72 & 3.6 & 81 & 3.7 \\
\hline Jordan & 70 & 4.1 & 41 & 3.9 & 47 & 4.4 \\
\hline Morocco & 67 & 4.2 & 105 & 3.3 & 41 & 4.6 \\
\hline Lebanon & 46 & 5.1 & 97 & 3.4 & 124 & 2.9 \\
\hline Tunisia & 78 & 3.9 & 107 & 3.3 & 55 & 4.1 \\
\hline Egypt & 80 & 3.8 & 129 & 3.0 & 67 & 3.8 \\
\hline Algeria & 103 & 2.8 & 133 & 2.9 & 130 & 2.7 \\
\hline
\end{tabular}

Source: author according to Baller, Dutta and Lanvin, 2016. ${ }^{22}$

The use of ICTs by governments in the region is far more intense. It has already been mentioned that, according to this criterion, the UAE government is in the second place in the world. Qatar, Bahrain, and Saudi Arabia are also ranked highly. Algeria is far behind in this, as well as the previous two pillars of this category, and it is in 130th place. The Lebanese government has far less use of ICTs (only 2.9 points) than individuals (5.1) and the economy of this country (3.4) (Table 4).

\section{ICTs impact}

The fourth and last category that defines the technological readiness of countries is the impact of ICTs on society and the economy. Economic impact

${ }^{22}$ Baller, Dutta, and Lanvin (eds), Technology Report 2016. 
is measured by the impact of ICTs on business and organisational models, on the rates of applied patents in the field of ICTs, and on the rates of jobs where there is a high share of knowledge. Social impact is measured by the impact of ICTs on access to basic services, internet access in schools, government efficiency, etc. In all Middle Eastern countries, the impact of ICTs on society is far greater than the economic impact. It is not about a high impact on society, but about a small impact on the economy. Given the dominance of the most technologically underdeveloped economic activity (energy exploitation), this outcome is quite expected.

ICTs have the greatest impact on society in the UAE, which is also ranked second in the world in this aspect, followed by Qatar and Bahrain, which also have a relatively high position in the world (Table 5).

Table 5. The impact of ICTs on the economy and society in the Middle east

\begin{tabular}{|c|c|c|c|c|c|c|}
\hline & \multicolumn{3}{|c|}{ Economic impact } & \multicolumn{3}{c|}{ Social impact } \\
\hline Rank & Country & Value & Rank & Value & Rank & Value \\
\hline 18 & UAE & 5.2 & 26 & 4.3 & 2 & 6.1 \\
\hline 27 & Qatar & 4.9 & 28 & 4.2 & 10 & 5.6 \\
\hline 32 & Bahrain & 4.5 & 48 & 3.5 & 13 & 5.5 \\
\hline 38 & S. Arabia & 4.3 & 40 & 3.7 & 36 & 4.9 \\
\hline 51 & Jordan & 3.9 & 61 & 3.4 & 53 & 4.4 \\
\hline 66 & Oman & 3.7 & 95 & 2.9 & 46 & 4.6 \\
\hline 80 & Morocco & 3.5 & 110 & 2.8 & 59 & 4.3 \\
\hline 84 & Tunisia & 3.4 & 93 & 2.9 & 78 & 3.9 \\
\hline 85 & Egypt & 3.4 & 58 & 3.4 & 103 & 3.5 \\
\hline 90 & Kuwait & 3.4 & 102 & 2.9 & 84 & 3.9 \\
\hline 103 & Lebanon & 3.2 & 83 & 3.1 & 114 & 3.3 \\
\hline 129 & Algeria & 2.6 & 124 & 2.6 & 132 & 2.7 \\
\hline
\end{tabular}

Source: author according to Baller, Dutta and Lanvin, 2016. ${ }^{23}$

\footnotetext{
${ }^{23}$ Baller, Dutta, and Lanvin (eds), Technology Report 2016.
} 


\section{EFFECTS OF INVESTING IN THE ICTS SECTOR IN THE MIDDLE EAST COUNTRIES}

Investing in itself, in any economic activity, increases the invested capital and thus helps increase labour productivity. Investing in a fast-growing sector, such as the ICTs sector, should provide additional impetus to growth and development. ${ }^{24}$ Computer hardware (computers, storage devices, printers, and other peripherals), computer software (operating systems, programming tools, applications, and internal software development), computer services (information technology consulting, computer and network system integration, Web hosting, data processing services, and other services), and communications services (voice and data communications services) are all included in the World Bank's definition of ICT expenditures. ${ }^{25}$ All this can be considered as areas of investment in ICTs.

Investment and spending in the ICTs sector are not covered by the World Economic Forum reports, and in general, data are very scarce and out of date. The latest and most accurate data was provided by the WITSA in the Digital Planet 2010 report (updated in 2013), based on reports from local member agencies. ${ }^{26}$ The expansion of ICTs use and investment in recent years has been so large that data is no longer collected even by the most important global statistical services such as the World Bank. Given that the aim of this research is to determine the correlation between investment in ICTS and economic parameters, i.e., to determine the relationship between the two time series, the lack of recent data is not of great statistical significance. In relation to the mentioned research by Stanojević, this correlation includes data on ICTs spending for 2019 and 2020, which were collected from various, mostly national sources in the form of statements by officials of the competent ministries and governments in the region. Such data are published (at least in English) for Saudi Arabia, Kuwait, Oman, and the UAE. ${ }^{27}$ In the meantime,

\footnotetext{
${ }^{24}$ Kotlica, Stanojević, Tehnologija, inovacije i konkurentnost u globalizovanoj privredi.

${ }^{25}$ World Bank, Information and Communication Technology Expenditure, Washington, D.C.: World Bank Group, 2020.

${ }^{26}$ WITSA, Digital planet 2010, Vienna, The World Information Technology and Services Alliance, 2014.

${ }^{27}$ Stanojević, Karakteristike privreda Bliskog istoka
} 
more detailed data were published by the competent ministries of Bahrain and Qatar, which are not covered by the aforementioned previous research, as well as Oman. A significant set of data for the Gulf countries was provided by the Saudi Communication and Information Technology Commission. ${ }^{28}$ Older data were used in the research for the other five countries of North Africa and Iran, so the results for them completely coincide with the results obtained in Stanojevićs research. ${ }^{29}$

Investment in information and communication technologies in the Middle East is listed in Table 6. Expenditure does not only refer to government investment, but total government, corporate, household, and individual consumption. For the statistical analysis that follows, the time series for the periods 2005-2013 and 2019-2020 were used, and in Table 6, for the sake of clarity in the text, only a part of the data is shown.

Table 6. Investment in ICTs sector

(Billion USD)

\begin{tabular}{|c|c|c|c|c|c|c|c|}
\hline & 2006 & 2008 & 2010 & 2012 & 2013 & 2019 & 2020 \\
\hline MENA & 52.8 & 77.7 & 91.7 & 110.6 & 117.8 & - & - \\
\hline Tunisia & 1.8 & 2.3 & 2.5 & 2.9 & 3.1 & - & - \\
\hline Egypt & 5.8 & 9.4 & 12.5 & 15.6 & 16.9 & - & - \\
\hline Bahrain & 0.8 & 0.8 & 1.0 & 1.2 & 1.5 & 1.4 & - \\
\hline Iran & 7.2 & 13.4 & 16.1 & 18.8 & 19.5 & - & - \\
\hline Jordan & 1.4 & 1.7 & 2.0 & 2.3 & 2.5 & 2.2 & 2.3 \\
\hline Kuwait & 3.6 & 4.9 & 5.2 & 6.3 & 6.7 & 8.8 & 9.1 \\
\hline S. Arabia & 17.6 & 25.4 & 32.9 & 39.5 & 42.1 & 35.2 & 36.8 \\
\hline Qatar & 2.6 & 3.2 & 3.5 & 3.6 & 3.8 & 4.1 & 4.2 \\
\hline
\end{tabular}

${ }^{28}$ CITC. ICT Report - ICT Investment in Saudi Arabia, Riyadh, Communication and Information Technology Commission, 2015.

${ }^{29}$ Stanojević, Karakteristike privreda Bliskog istoka. 


\begin{tabular}{|c|c|c|c|c|c|c|c|}
\hline & 2006 & 2008 & 2010 & 2012 & 2013 & 2019 & 2020 \\
\hline Oman & 2.4 & 3.0 & 3.1 & 2.9 & 3.0 & 3.2 & - \\
\hline UAE & 7.8 & 11.5 & 12.3 & 15.3 & 16.5 & 15.9 & 16.3 \\
\hline Algeria & 2.9 & 3.8 & 4.3 & 4.8 & 5.3 & - & - \\
\hline Morocco & 4.9 & 9.8 & 11.9 & 14.2 & 15.0 & - & - \\
\hline
\end{tabular}

Source: WITSA, 2014; CITC, 2015. ${ }^{30}$

The data show that the total spending on ICTs in the Middle East region amounts to slightly more than 140 billion dollars in 2013, and it is by far the largest in Saudi Arabia, as much as 42 billion. It is followed by Iran with 19 and Egypt and the United Arab Emirates with 18 billion dollars. Despite many years of extensive investment by the state and the growth of individual consumption, Saudi Arabia lags behind in terms of technological indicators compared to the UAE because the application and use of ICTs is at a very low level.

However, globally, these countries have extremely low spending in the ICTs field. Many developed countries individually have a similar volume of consumption to all Arab countries combined, although some of the richest countries, such as Saudi Arabia and the UAE, are also here. ${ }^{31}$ For example, Canada, France, Italy, and India have about the same spending as all Arab countries combined. While Germany and the UK spend over $\$ 200$ billion a year on ICTs, Brazil, which is not a developed country, spends $\$ 110$ billion. Japan $\$ 400$ billion, China about $\$ 550$ billion, and the US $\$ 1260$ billion a year. ${ }^{32}$

The correlation between investment in ICTs and GDP, as well as ICTs and GDP per capita, was calculated using the Pearson correlation coefficient. It is a measure of the intensity of a linear relationship between two variables and can have values between +1 and -1 . A value of 0 indicates that there is no relationship between these two variables. A value greater than 0 indicates a positive relationship; that is, as the value of one variable increases, so does

\footnotetext{
30 WITSA, Digital planet 2010; CITC, ICT Report.

${ }^{31}$ Stanojević, Karakteristike privreda Bliskog istoka.

32 WITSA, Digital Planet 2010, 23.
} 
the value of the other variable. A value less than 0 indicates a negative relationship; that is, as the value of one variable increases, the value of the other decreases.

The equation for the Pearson correlation coefficient is:

$$
\mathrm{r}=\frac{\Sigma(x i-\bar{x})(y i-\bar{y})}{\sqrt{\Sigma(x i-\bar{x})^{2}} \Sigma(y i-\bar{y})^{2}}
$$

Where:

\begin{tabular}{ll}
$r$ & \multicolumn{1}{c}{ correlation coefficient } \\
$x i$ & values of the $x$-variable in a sample \\
$x$ & mean of the values of the $x$-variable \\
$y i$ & values of the $y$-variable in a sample \\
$y$ & mean of the values of the $y$-variable
\end{tabular}

By applying the Pearson coefficient to all countries in the region and all years for which data are available, with investment in ICTs as an independent variable and the dependent variables GDP and GDP per capita, the following results were obtained.

Investments in ICTs in the Middle Eastern economies have a large positive impact on the growth of these economies, while the impact on GDP growth per capita shows some differences. In Tunisia, Iran, Egypt, Morocco, Algeria, Pakistan, and Saudi Arabia, the Pearson ratio is over 0.95 and $96-99 \%$, respectively, which is similar to the analysis of the impact on GDP. Deviations are observed in the case of Jordan, where the impact is around $72 \%$, and, paradoxically, a large negative impact was measured in the United Arab Emirates and Kuwait.

This, of course, does not mean that economic growth per capita is declining due to investment in ICTs, especially since total GDP grew in this period and showed a high correlation with investment in ICTs. 
Table 7. Effects of investment in ICTs on economic growth

\begin{tabular}{|c|c|c|}
\hline Country & $\begin{array}{c}\text { Pearson coefficient } \\
\text { for GDP }\end{array}$ & $\begin{array}{c}\text { Pearson coefficient } \\
\text { for GDP per capita }\end{array}$ \\
\hline Tunisia & 0.931 & 0.975 \\
\hline Egypt & 0.997 & 0.970 \\
\hline Iran & 0.951 & 0.911 \\
\hline Jordan & 0.994 & 0.727 \\
\hline Qatar & 0.933 & 0.912 \\
\hline Kuwait & 0.952 & -0.136 \\
\hline S. Arabia & 0.914 & 0.947 \\
\hline UAE & 0.968 & -0.731 \\
\hline Oman & 0.922 & 0.941 \\
\hline Algeria & 0.965 & 0.995 \\
\hline Morocco & 0.977 & 0.988 \\
\hline Pakistan & 0.969 & 0.993 \\
\hline
\end{tabular}

Source: author`s calculation

As GDP per capita declined while total GDP grew, it can only be concluded that these two countries recorded a large increase in population over a period of several years, which was reflected in the data on GDP per capita. As the birth rate cannot increase so sharply, it is most likely that in this period, the UAE and Kuwait, as rich oil economies, had a large immigration inflow as a result of the post-2008 World Economic Crisis.

\section{CONCLUSIONS}

The focus of this research is the possibility of including the Middle East region in the group of developed countries, as it already meets some of the key criteria, such as a high standard of living, high incomes, and modern infrastructure.

Among the many factors of competitiveness, such as macroeconomic stability, institutions, market size, skills, and others, ICTs adoption stands out 
as a potential driver of future growth in the competitiveness of the Middle Eastern economies. The development of information, and especially communication technologies, has been analysed both as a goal and as a means of convergence for the developed world. For a region in the Middle East that does not have the natural potential to develop industry, this is one of the few opportunities to achieve development.

Research has shown that many countries in the Middle East do not lag behind other regions of the world in terms of key categories by which the degree of technological readiness is assessed. The lag was recorded only in relation to the most developed economies, which confirms the hypothesis that ICT can be a successful driver of development in these countries.

In three of the four categories that assess technological readiness, the Middle East is ahead of Eurasia and the emerging economies of Europe and Asia, and in all four it is ahead of Latin America and Africa. Indicators in which the region lags slightly behind emerging economies and lags the most behind developed countries are ICTs skills in the poorer countries of the region and ICTs availability in the richest countries in the Middle East. The first lower indicator of ICTs skills confirmed the second part of the general hypothesis about the mixed effects of ICTs, due to the low capacity of labour and the population in general to absorb new technologies. Because the criterion for judging the price indicators of Internet services and mobile telephony services, which are high in these countries due to the high standard, and are in fact widely available, the latter indicator of ICTs availability is not a real obstacle.

In other categories (ICTs environment, ICTs usage, and ICTs impact), although collectively not lagging behind other regions, many countries are ranked very low in terms of the usage of ICTs by governments and businesses.

The most important results of this research are that the countries of the Middle East have the opportunity to join the so-called developed world and get closer to developed economies by engaging in the field of ICTs development. Although the investment relates to hardware and software development, the Middle Eastern countries do not have an industry that would support the former, nor enough human resources to contribute significantly to the latter. On the other hand, a significant incentive to include the Middle East in the group of developed economies would be investments in services, such as communications services (voice and data communications 
services), as well as data processing services, computer and network systems integration, Web hosting, etc.

In addition to capital investment, which many countries in the region do not lack, many segments of ICTs development require only the greater involvement of governments in the region (without investment) in terms of more intensive use of ICTs by governments and businesses.

\section{BIBLIOGRAPHY}

Baller, Silja, Dutta, Soumitra. and Lanvin, Bruno (editors). Technology Report 2016 - Innovating in the Digital Economy. Geneva: World Economic Forum, 2016.

CITC, ICT Report - ICT Investment in Saudi Arabia. Riyadh: Communication and Information Technology Commission, 2015.

Hanclova, Jana, Doucek, Petr, Fischer, Jacub, \& Vltavska, Kristyna. "Does ICT capital affect economic growth in the EU-15 and EU-12 countries?" Journal of Business Economics and Management, 16(2), 2015: 387-406. DOI: https://doi.org/10.3846/16111699.2012.754375

Karlsson Emil and Liljevern Jennie. ICT Investment and the Effect on Economic Growth - a Comparative Study across Four Income Group. Jönköping: Jönköping University, 2017.

Kotlica, Slobodan and Stanojević, Nataša. Tehnologija, inovacije i konkurentnost u globalizovanoj privredi. Beograd: Dositej, 2017.

Niebel Thomas. "ICT and Economic Growth - Comparing Developing, Emerging and Developed Countries," World Development, 104(C), 2018: 197-211. DOI: 10.1016/j.worlddev.2017.11.024

O'Mahony, Mary and Vecchi, Michela. "Quantifying the Impact of ICT Capital on Output Growth: A Heterogeneous Dynamic Panel Approach", Economica 72(288), 2005: 615-633. https://doi.org/10.1111/j.14680335.2005.0435.x

Papaioannou, Sotiris and Dimelis Sophia. "Information Technology as a Factor of Economic Development: Evidence from Developed and Developing Countries," Economics of Innovation and New Technology, 16(3), 2007:179-194. 
Pilat, Dirk. "The ICT Productivity Paradox: Insights from Micro Data", OECD Economic Studies, 1, 2004: 37-65.

Schwab, Klaus. (ed.). The Global Competitiveness Report 2019, Geneva: World Economic Forum, 2019.

Stanojević, Nataša, Karakteristike privreda Bliskog istoka i Severne Afrike i perspektive ekonomske saradnje sa Srbijom, Institut za međunarodnu politiku i privredu, Beograd, 2021.

Stiroh, Kevin. "Are ICT Spillovers Driving the New Economy"? Review of Income and Wealth, 48(1), 2002: 33-57.

Strauss, Hubert and Samkharadze, Besik. "ICT Capital and Productivity Growth." EIB Papers, 16(2), 2011:8-28.

UNCTAD. World Investment Report 2017 - The digital economy - the application of internet-based digital technologies to the production and trade of goods and services, Geneva: United Nations, 2017.

UNCTAD. World Investment Report 2018 - Investment and New Industrial Policies, Geneva: United Nations, 2018. https://unctad.org/en/ PublicationsLibrary/wir2018_en.pdf

Vu, Khuong M. "ICT as a Source of Economic Growth in the Information Age: Empirical Evidence from the 1996-2005 Period". Telecommunications Policy, 35(4), 2011: 357-372.

WITSA. Digital planet 2010, Vienna, The World Information Technology and Services Alliance, 2014. https://witsa.org/wp-content/uploads/2019/03/ DP2010_Revised_0519.pdf

World Bank. ICT for Greater Development Impact. Washington, D.C.: World Bank Group, 2012.

World Bank. Information and Communication Technology Expenditure, Washington, D.C.: World Bank Group, 2020. https://datacatalog.world bank.org/information-and-communication-technology-expenditure-gdp

Yousefi, Ayoub. "The impact of information and communication technology on economic growth: evidence from developed and developing countries", Economics of Innovation and New Technology, 20(6), 2011: 581-596. 